\title{
Patent Analyst
}

\section{Patent injunctions in Europe: the return of the pan-European injunction - or how can you get a decision from one court effective in more than one country?}

\begin{abstract}
"We are on the final lap of the journey toward the creation of a 'Unified Patent Court' that will ... be able to grant injunctions effective in every country where the patents are in force."
\end{abstract}

Keywords: injunctions • Pan-European injunctions • patents $\bullet$ Unified Patent Court

When a European patent is granted, it becomes, in effect, a 'bundle' of national patents in every country where it has been validated. The text and claims are the same everywhere, and (in theory at least) the law in each country on the validity and infringement of patents is the same. If an infringing product is being sold across Europe, why, then, can you not bring one set of proceedings and obtain an injunction effective in every country?

One answer is that you can, but not yet. We are on the final lap of the journey toward the creation of a 'Unified Patent Court' that will hear cases involving all the patents in a European 'bundle' of patents, and will be able to grant injunctions effective in every country where the patents are in force. This new court will not open its doors until September 2016 at the earliest, and maybe not until 2017. Even when the new court opens for business, the pharmaceutical industry is expected to view it with caution. Pharmaceutical patents are very valuable, and although it would be a major advantage to win an injunction across Europe in one legal action, the downside is that, if you lose, the patent is lost across the whole of Europe. For this reason, pharmaceutical companies will probably stick to enforcing their patents in a multiplicity of proceedings in national courts, at least until there has been some experience of how the new court will operate in practice.
Until the Unified Patent Court is up and running, we have to sue in the national courts. The rules about which national court can deal with what cases against what infringers are set out in the Brussels Regulation [1].

The basic rule in the Brussels Regulation is that you sue a company where it is domiciled (in effect, where it has its head office) (as an alternative, you can sue the company in a country where the infringing acts take place). This works well if the company is the manufacturer of the infringing product, and you do not want to sue its distributors, or if the company is itself selling the product in a number of different countries. However, that is not what normally happens: most companies have subsidiaries in each country which are responsible for sales in that country. Does the Brussels Regulation let you sue all these companies together in one court?

In the early 2000s, the Dutch court answered 'yes' to that question. So long as the company (domiciled in The Netherlands) which you sued in the Dutch court was the company in overall control of the group, you could add its subsidiaries across Europe as additional defendants, and the Dutch court could grant an injunction against them all. The Brussels Regulation also provides that courts in Europe must enforce orders made by other courts in Europe, so these 'pan-European' injunctions were very effective. The courts in other

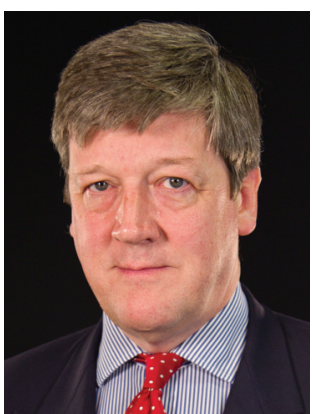

Rowan Freeland ${ }^{*}, 1$ 'Partner, Patent Litigation at Simmons \& Simmons LLP, London, UK *Author for correspondence: rowan.freeland@ simmons-simmons.com 
countries were beginning to follow the same approach when the European Court of Justice (ECJ) put a stop to it in two ways.

First, the Brussels Regulation provides that cases about the validity of a patent can only be heard in the country where the patent is in force. This clearly applies where you start nullity proceedings to revoke a patent. Does it also apply where the validity of a patent is raised as a defense to a claim for infringement? In a case called GAT $v L u K$ [2], a German company was sued in Germany in respect of an infringement committed in France. It said that it wanted to argue in its defense that the French patent was invalid, and argued that this meant that the case could not continue in Germany. The ECJ agreed with this approach. If you have sued companies from across Europe for infringement of their local patents in front of one court, the ECJ said that that court could not hear the case if the infringers wanted to argue that the patents in their home countries were invalid.

Second, the Brussels Regulation provides that you can bring in defendants from other countries if the cases against them are so closely connected that, if you sued each one in their own local court, there would be a risk of 'irreconcilable' judgments. The Dutch courts took the view that if the courts in country A were to decide that the patent was infringed, while the courts in country B were to decide that it was not infringed, these two judgments were irreconcilable (this is not a fanciful possibility; patent cases frequently turn on issues where reasonable men may differ, and there are many examples where the courts in different countries have come to different conclusions. The most recent example is in the Actavis case discussed below - there was a parallel German action where the German court both at first instance and on appeal came to the opposite decision to the corresponding English court). To avoid that risk, the Dutch courts said that it was permissible to sue the infringers from country $A$ and the infringers from country $B$ in the same court. The ECJ disagreed. In a case called Roche $v$ Primus [3], it decided that, although different results in different countries might be inconvenient, judgements on patent infringement were only irreconcilable' if cases against different companies in the same country came to different results. So it was not legitimate to rely on the 'irreconcilable judgments' rule in the Brussels Regulation to sue infringers from different countries in one national court.

These two decisions from the ECJ put a stop to attempts to get one court to decide on patents in more than one country for the best part of 10 years. Two recent cases have started to look at multicountry patent disputes again.

The first case was Solvay v Honeywell [4], another case in the ECJ. Solvay discovered that Honeywell's local subsidiaries in The Netherlands and in Belgium were both selling products in Sweden and Denmark which Solvay considered were infringements of one of its patents. Solvay sued both of them in the Dutch court. The question was whether Honeywell Belgium had properly been made a part of those proceedings, in order to avoid 'irreconcilable' judgments. The ECJ's answer, of course, was that it was: it would have been ridiculous if the Dutch court decided that Honeywell Netherlands would infringe if it sold the product in Sweden and Denmark, but the Belgium Court decided that Honeywell Belgium would not infringe if it sold the same product in the same two countries.

The second case was the decision of the English courts in Actavis v Eli Lilly [5]. In all of the above cases, the patent owner was trying to sue different companies for infringements committed in different countries. The Actavis case turns this on its head: Actavis sued Eli Lilly for a declaration that its proposed product did not infringe a European patent owned by Eli Lilly, not only for the UK designation, but also for the French, Italian and Spanish designations. Actavis did not challenge to validity of the patents in those countries, and so avoided the rule from GAT $v L u K$ that patent validity is exclusively a matter for the courts of the country where the patent was in force. The English courts agreed with Actavis that the claim was permissible (since Eli Lilly was an American company, the rules in the Brussels Regulation did not apply, and the decision about whether it has been properly sued in England was decided under English law, but the outcome would have been the same if Eli Lilly had been a European company being sued in its country of domicile). Interestingly, Eli Lilly had the last laugh, since the English Court of Appeal decided that, at least in certain circumstances, the Actavis product would infringe Eli Lilly's patent.

It is clear from the Solvay and Actavis cases that it is still possible in some circumstances to get one national court to make a decision about patent infringement which is effective in more than one country. However, the circumstances in which this can be achieved are limited and set about with legal technicalities. While, no doubt, clever lawyers and their clients are working on new ways to secure strategic advantages by making claims not limited to one country, to get truly effective pan-European relief, we will have to wait for the Unified Patent Court. 
Financial \& competing interests disclosure

The author has no relevant affiliations or financial involvement with any organization or entity with a financial interest in or financial conflict with the subject matter or materials discussed in the manuscript. This includes employment, consultancies, honoraria, stock ownership or options, expert testimony, grants or patents received or pending, or royalties.

No writing assistance was utilized in the production of this manuscript.

\section{References}

EU Regulation No 1215/2012.

ECJ Case number C-4/03 dated 13 July 2006.

ECJ Case number C-539/03 dated 13 July 2006.

ECJ Case number C-616/10 dated 12 July 2012.

5 [2013] EWCA Civ 517, upholding [2012] EWHC 3316 (Pat). 